\title{
Impact of Simultaneous Exposure to Lead and Efavirenz on Some Biochemical Markers in Wistar Rats
}

\author{
Alain K. Aïssi ${ }^{1 *}$, Lauris Fah ${ }^{1}$, Casimir D. Akpovi ${ }^{1}$, Jean Robert Klotoé ${ }^{1}$, Victorien T. Dougnon ${ }^{1}$, Patient Guédénon $^{2}$, Patrick A. Edorh ${ }^{2,3}$ and \\ Frédéric Loko ${ }^{1}$ \\ ${ }^{1}$ Research Laboratory in Applied Biology, Polytechnic School of Abomey-Calavi, University of Abomey-Calavi, Benin \\ ${ }^{2}$ Interfaculty Center of Formation and Research in Environment for the Sustainable Development, Laboratory of Toxicology and Environmental Health, University of \\ Abomey-Calavi (UAC), 01 BP 1463 Cotonou, Benin \\ ${ }^{3}$ Department of Biochemistry and Cellular Biology, Faculty of Science and Technology, University of Abomey-Calavi, Benin
}

\begin{abstract}
Chronic exposure to heavy metals including lead remains a serious problem for humanity. The current study aims to evaluate the impact of co-exposure to lead $(\mathrm{Pb})$ and Efavirenz (EFV) on some biochemical parameters in blood. Twenty eight Wistar rats were divided equally into four groups respectively orally fed with lead acetate at $10 \mathrm{mg} / \mathrm{kg}\left(\mathrm{G}_{\mathrm{pb}}\right)$, EFV at $20 \mathrm{mg} / \mathrm{kg}\left(\mathrm{G}_{\mathrm{EFv}}\right)$, both xenobiotics $\left(\mathrm{G}_{\mathrm{Pb}+\mathrm{EFV}_{\mathrm{V}}}\right)$, and distilled water $\left(\mathrm{G}_{\mathrm{Ctrr}}\right)$. On Day 0 and Day 28 , the blood of each animal was collected and biochemical assays were conducted. Data were processed with SPSS 16.0. The results showed a significant decrease in total proteinemia, albuminemia, serum calcium and iron as well as a significant increase in blood urea and uric acid in groups exposed to lead. The aforementioned changes were more pronounced in group $G_{p b+E f v^{*}}$ Besides, significant increases in total cholesterolemia were observed in $G_{E f v}$ and $G_{P b+E F v}$. In contrast, changes in blood glucose and triglycerides were not significant. In conclusion, this study highlights a real problem of public health, in the light of thousands of patients receiving antiretroviral therapy and who are unintentionally exposed to heavy metals.
\end{abstract}

Keywords: Lead; Efavirenz; Biochemical parameters; Heavy metal; Antiretroviral drug; Wistar rats.

\section{Introduction}

The humanity is increasingly confronted to health risks linked to pollution of air, water, soil, fauna and flora by toxic xenobiotics $[1,2]$. In Benin like most West African States, several studies have reported increasing threats by heavy metal poisoning including lead which occupies a dominating place [3-5]. The levels of this inorganic chemical pollutants are indeed often higher than the maximum allowable concentrations particularly in some drinking water [6,7] and foods commonly consumed [8-11].

Lead is an inducer of oxidative stress [12-16] with proven toxic effects in nervous system [13,17], hematopoietic system, cardiovascular system, reproductive system, liver and kidneys functions [14]. Its absorption is stronger in children [17] and people with protein deficiency or mineral deficiency or excess fat [13].

This could be the case in people immunosuppressed by HIV and who are permanently exposed to the risk of adverse reactions linked to antiretroviral drugs (ARVs) $[18,19]$. Indeed, despite their efficacity in the improvement of survival of patients [20], the ARVs therapy can induce oxidative stress which is often correlated to disturbances in biological nutritional markers $[18,21]$.

It is in this context that we decided to better know the adverse effects of lead poisoning during antiretroviral treatment. Thus, the current study proposes to evaluate the impact that could have the absorption of lead and Efavirenz on some biochemical parameters. Efavirenz drugs has been selected because it is a very privileged ARVs in pregnant women, children over three years, co-infected patients with HIV and TB according to news recommendations of WHO [20].

\section{Material and Methods}

\section{Study area}

This work was carried out in Benin, particularly at the Research
Laboratory in Applied Biology, located at Polytechnic School of Abomey-Calavi in University of Abomey-Calavi. It extended from 02 June to 30 December 2013.

\section{Animal material}

Twenty eight (28) Wistar rats were used. After their acquisition, the animals aged 2 to 4 weeks were acclimated for 8 weeks in order to fully adapt to their new environment and acquire means weight of about 150 g. Cages were placed in a well-ventilated room with alternating light and dark periods of 12 hours each. Drinking water was available ad libitum and the standard rodent diet was renewed every morning.

\section{Chemical material}

It is on one hand, a solution of lead acetate at $10 \mathrm{mg} / \mathrm{mL}$ and on the other hand, Efavirenz in powder whose $200 \mathrm{mg}$ were diluted daily in distilled water so as to obtain a $5 \mathrm{mg} / \mathrm{mL}$ solution.

\section{Distribution of rats and administration of xenobiotics}

Rats were weighed and randomly divided into four (04) groups of seven. The groups were identified according to the following exposure regimes:

- $\mathrm{G}_{\mathrm{Ctrl}}=$ group of control rats that received $0.5 \mathrm{ml}$ of distilled water

${ }^{*}$ Corresponding author: Alain K. Aïssi, Research Laboratory in Applied Biology, Polytechnic School of Abomey-Calavi, University of Abomey-Calavi, Benin, Tél: +22995784471; E-mail: alkaiss2ieme@gmail.com

Received April 04, 2014; Accepted May 06, 2014; Published May 08, 2014

Citation: Aïssi AK, Fah L, Akpovi CD, Klotoé JR, Dougnon VT, et al. (2014) Impact of Simultaneous Exposure to Lead and Efavirenz on Some Biochemical Markers in Wistar Rats. J Environ Anal Toxicol 4: 220. doi: 10.4172/2161-0525.1000220

Copyright: @ 2014 Aïssi AK, et al. This is an open-access article distributed under the terms of the Creative Commons Attribution License, which permits unrestricted use, distribution, and reproduction in any medium, provided the original author and source are credited. 
- $\mathrm{G}_{\mathrm{Pb}}=$ group of rats treated with $10 \mathrm{mg} / \mathrm{kg}$ of lead acetate. This dose was chosen in accordance to several studies [13,22].

- $\mathrm{G}_{\mathrm{Efv}}=$ group of rats treated with $20 \mathrm{mg} / \mathrm{kg}$ of Efavirenz. It is the maximum daily dose required in a human child infected with HIV [23]. This choice was done in accordance to the dose used by Adjene et al. [21].

- $\mathrm{G}_{\mathrm{Pb}+\mathrm{Efv}}=$ group of rats treated with $10 \mathrm{mg} / \mathrm{kg}$ of lead acetate and $20 \mathrm{mg} / \mathrm{kg}$ of EFV

The administration of xenobiotics was made through the orogastric tube for 28 days every morning between 7:00 am and 8:30 am.

\section{Blood collection and biochemicals analysis}

Blood samples were collected on Day 0 and Day 28 from eye vein in a collection tube without anticoagulant (Vacutainer System; Becton Dickinson) such as described in Hassan and Jassim [24]. They were properly labeled and placed directly on a rack into a cool-box containing icepacks. Serums were separated from the blood cells after centrifugations at $2500 \mathrm{rpm}$. Total protein, albumin, urea, glucose, uric acid, total cholesterol, triglycerides, iron and calcium were measured by using Elitech Clinical Chemistry reagents on analyzer Mindray BS200.

\section{Statistical analysis}

Means and standard deviations for each parameter were calculated using SPSS 16.0 software. Values were checked for homogeneity of variances thanks to the Levene's test. Then, a one-way analysis of variance (ANOVA) followed by the post hoc Bonferroni multiple comparisons test were carried out for comparing mean levels and detect specific significances differences between groups when $p<0.05$. The rates of changes in all parameters from Day 0 to Day 28 were calculated and the significativity of decrease or increase were evaluated using the Student's t test with a $95 \%$ confidence level. The graphs were designed using Graph Pad Prism software 5.03.

\section{Results and Discussion}

\section{Protidic parameters concentrations}

Total blood protein: 28 days after exposure, the mean of total proteinemia (Figure 1) was significantly decreased by $29.3 \%(65.24$ to $46.14 \mathrm{~g} / \mathrm{L})$ in $\mathrm{G}_{\mathrm{Pb}}(\mathrm{p}=0.00662)$, by $16.6 \%$ (65.67 to $\left.54.79 \mathrm{~g} / \mathrm{L}\right)$ in $\mathrm{G}_{\mathrm{Ef}}$ $(\mathrm{p}=0.00205)$ and by $29.8 \%(63.67$ to $44.70 \mathrm{~g} / \mathrm{L})$ in $\mathrm{G}_{\mathrm{pb}+\mathrm{Efv}}(\mathrm{p}=0.00756)$. The difference of the rate of decrease in this parameter between the groups $\mathrm{G}_{\mathrm{Pb}}$ and $\mathrm{G}_{\mathrm{EFv}}$ was significant $(p=0.01871)$, but that observed between $\mathrm{G}_{\mathrm{Pb}}$ and $\mathrm{G}_{\mathrm{Pb}+\mathrm{Efv}}$ is not.

Serum albumin: The mean of albuminemia (Figure 2) was significantly decreased by $33.9 \%$ ( 34.68 to $22.90 \mathrm{~g} / \mathrm{L}$ ) in $\mathrm{G}_{\mathrm{Pb}}(\mathrm{p}=0.01125$ ) by $18.8 \%$ (32.41 to $26.31 \mathrm{~g} / \mathrm{L})$ in $\mathrm{G}_{\mathrm{Efv}}(\mathrm{p}=0.02339)$ and by $26.8 \%(30.19$ to $22.10 \mathrm{~g} / \mathrm{L})$ in $\mathrm{G}_{\mathrm{Pb}+\mathrm{Efv}}(\mathrm{p}=0.01601)$. The difference between the mean level of serum albumin in $\mathrm{G}_{\mathrm{Pb}}$ and $\mathrm{G}_{\mathrm{Efv}}$ groups is not significant. It is the same between $\mathrm{G}_{\mathrm{Pb}}$ and $\mathrm{G}_{\mathrm{Pb}+\mathrm{Efv}}$.

Blood urea: From Day 0 to Day 28, the mean of blood urea (Figure 3) was increased by more than 2 times in the groups $\mathrm{GPb}$ and $\mathrm{GP} b+E f v$, passing respectively from 0.20 to $0.45 \mathrm{~g} / \mathrm{L}(\mathrm{p}=0.00713)$ and from 0.21 to $0.48 \mathrm{~g} / \mathrm{L}$ ( $\mathrm{p}=0.00065)$. Changes in GCtrl and GEfv groups were not significant. The increase in the rate of the mean level of blood urea in $\mathrm{GPb}$ significantly exceeds that observed in GEfv ( $\mathrm{p}=0.01066)$. But there is no significant difference between the increase in GPb compared to $\mathrm{GPb}+E f v$.

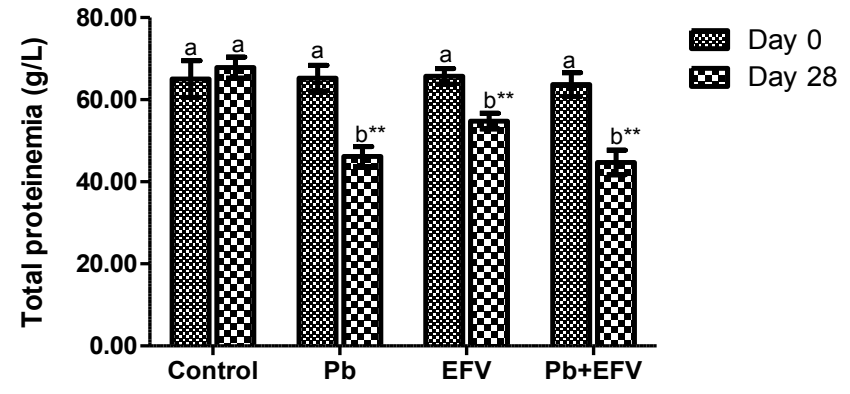

${ }^{* *} p<0.01$; Values of Day 0 with the same letter (a) are not significantly different Values of Day 28 with letter (b) are statistically different from those of Day 0 in the same column

Figure 1: Total proteinemia levels in control rats and in rats exposed to xenobiotics.

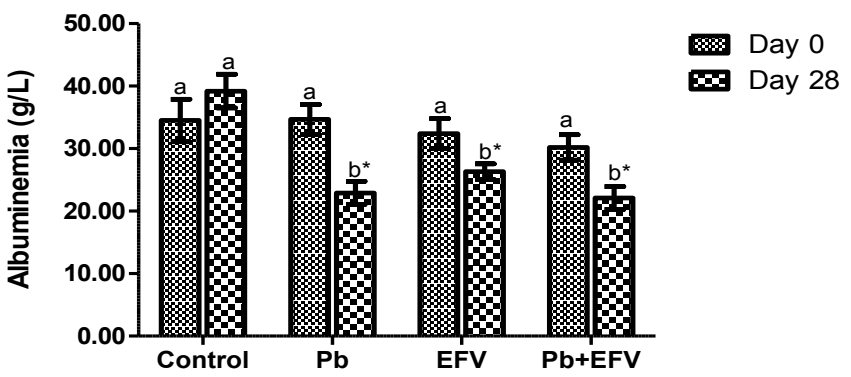

${ }^{*} p<0.05$; Values of Day 0 with the same letter $\left({ }^{a}\right)$ are not significantly different. Values of Day 28 with letter $\left(^{b}\right)$ are statistically different from those of Day 0 in the same column

Figure 2: Albuminemia levels in control rats and in rats exposed to xenobiotics.

Blood uric acid concentrations: From Day 0 to Day 28, the mean of uricemia (Figure 4) was significantly increased in all groups except $\mathrm{G}_{\mathrm{Ctrl}}$. This increase was by $73.1 \%$ (33.02 to $57.16 \mathrm{mg} / \mathrm{L}$ ) in $\mathrm{G}_{\mathrm{Pb}}$ $(\mathrm{p}=0.00223)$ and by $90.9 \%$ (31.96 to $61.00 \mathrm{mg} / \mathrm{L})$ in $\mathrm{G}_{\mathrm{Pb}+\mathrm{Efv}}(\mathrm{p}=0.00089)$. The difference of the rate of increase in the mean of blood uric acid is significant between $\mathrm{G}_{\mathrm{Pb}}$ and $\mathrm{G}_{\mathrm{Efv}}$ i.e. $48.5 \%(\mathrm{p}=0.00131)$. But between $\mathrm{G}_{\mathrm{Pb}}$ and $\mathrm{G}_{\mathrm{Pb}+\mathrm{Efv}}$, no significant difference was noted.

Blood glucose concentrations: No significant changes in the mean of blood glucose were noted whatever comparisons made between the four experimental groups (Figure 5).

\section{Blood lipids concentrations}

Total cholesterolemia: From Day 0 to Day 28, the mean of total cholesterolemia was increased significantly in $\mathrm{G}_{\mathrm{Efv}}(\mathrm{p}=0.00261)$ and $\mathrm{G}_{\mathrm{Pb}+\mathrm{Efv}}(\mathrm{p}=0.00827)$ with respective rate of increase of $35.2 \%$ ( 0.80 to $1.08 \mathrm{~g} / \mathrm{L}$ ) and $32.2 \%(0.86$ to $1.13 \mathrm{~g} / \mathrm{L})$. The changes in this parameter in the others groups $\left(\mathrm{G}_{\mathrm{Ctrl}}\right.$ and $\left.\mathrm{G}_{\mathrm{Pb}}\right)$ were not significant (Figure 6).

Triglyceridemia: From Day 0 to Day 28, the mean of blood triglyceride (Figure 7) was increased insignificantly in the four different experimental groups.

\section{Mineral nutrients concentrations}

Serum iron: From Day 0 to Day 28, the mean of serum iron (Figure 8) was significantly decreased by $58.3 \%$ (1.85 to $0.77 \mathrm{mg} / \mathrm{L}$ ) in $\mathrm{G}_{\mathrm{pb}}$ $(\mathrm{p}=0,00170)$ and by $66.0 \%(1.74$ to $0.59 \mathrm{mg} / \mathrm{L})$ in $\mathrm{G}_{\mathrm{Pb}+\mathrm{Efv}}(\mathrm{p}=0.00087)$. 


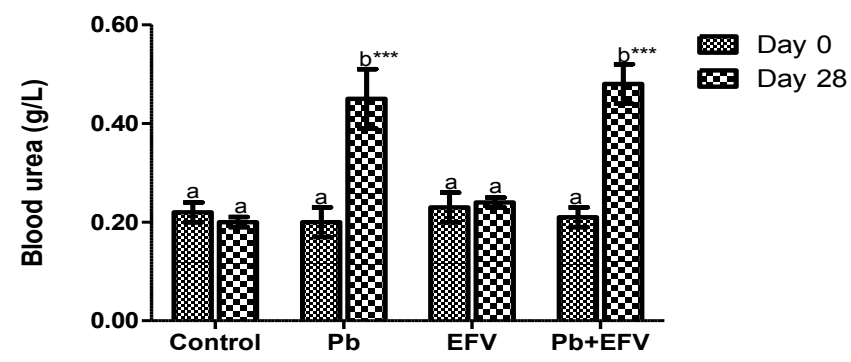

${ }^{* * *} p<0.001$; Values of Day 0 with the same letter (a) are not significantly different. Values of Day 28 with letter (b) are statistically different from those of Day 0 in the same colum

Figure 3: Blood urea levels in control rats and in rats exposed to xenobiotics.

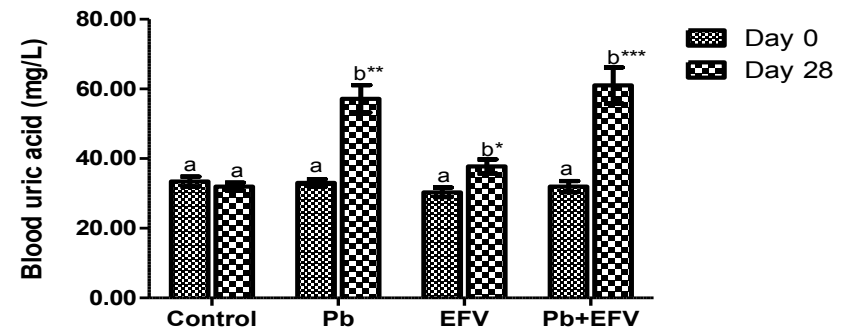

${ }^{*} p<0.05 ;{ }^{* *} p<0.01 ;{ }^{* * *} p<0.001 ;$ Values of Day 0 with the same letter (a) are not significantly different. Values of Day 28 with letter (b) are statistically different from those of Day 0 in the same column

Figure 4: Blood uric acid levels in control rats and in rats exposed to xenobiotics.

Changes in $\mathrm{G}_{\mathrm{Ctrl}}$ and $\mathrm{G}_{\mathrm{Efv}}$ were not significant (Figure 8). The difference between the rate of decrease in this parameter in $\mathrm{G}_{\mathrm{Pb}}$ compared to $\mathrm{G}_{\mathrm{Efv}}$ or to $\mathrm{G}_{\mathrm{Pb}+\mathrm{Efv}}$ was not significant.

Blood calcium: The mean of blood calcium was decreased significantly by $21.8 \%$ ( 80.4 to $62.9 \mathrm{mg} / \mathrm{L})$ in $\mathrm{G}_{\mathrm{Pb}}(\mathrm{p}=0.00429)$ and by $24.1 \%(78.9$ to $59.9 \mathrm{mg} / \mathrm{L})$ in $\mathrm{G}_{\mathrm{pb}+\mathrm{Efy}}(\mathrm{p}=0.00142)$. In the others groups $\left(G_{\mathrm{Ctrl}}\right.$ and $\left.\mathrm{G}_{\mathrm{Efv}}\right)$, the decrease in this parameter was not significant (Figure 9). The decrease in the mean level of serum calcium in the $\mathrm{G}_{\mathrm{Pb}}$ group exceeds significantly by $15.1 \%(p=0.02326)$ that observed in $\mathrm{G}_{\mathrm{Efv}}$. But between $\mathrm{G}_{\mathrm{Pb}}$ and $\mathrm{G}_{\mathrm{Pb}+\mathrm{Efv}}$, no significant difference was observed.

\section{Discussion}

\section{Impact of lead acetate on biochemical parameters}

The signs of chronic lead poisoning are usually non-specific, discreet and insidious [13]. In this study, the daily dose of $10 \mathrm{mg} / \mathrm{kg}$ of lead acetate we used has been considered by some authors as a low dose in rats [25,26]. Saka et al. [13], during their experience wherein increasing doses of lead acetate $(25,50$ and $100 \mathrm{mg} / \mathrm{kg})$ have been administered in rats for one week, had also found a highly significant decrease in protéinemia and an increase in blood urea and uric acid concentration. Missoun et al. [27] showed that rats exposure to 1000 ppm of lead acetate in drinking water for 8 weeks causes hypercalcemia.

Unlike our results wherein the variability in blood glucose was not affected, Saka et al. [13] report that the lead (from $50 \mathrm{mg} / \mathrm{kg}$ ) causes a significant increase in glycemia. Missoun et al. [27] on the other hand have found that lead acetate induce a decrease in this parameter.

Furthermore, the insignificant changes in total cholesterolemia after lead exposure is in accordance with findings of Hassan and Jassim [22] but is opposed to those of Moussa and Bashandy [28] who have noted an increase in this blood lipid level after rats exposure to lead (via drinking water containing $20000 \mathrm{ppm}$ of lead acetate) for a month. Triglyceride concentrations have remained normal according to our results unlike those of Hassan and Jassim [22] who found that administration of lead acetate at $10 \mathrm{mg} / \mathrm{kg}$ induce a decrease in triglyceridemia in rats.

The decrease in total proteinemia and in serum albumin particularly might be due to an alteration of their metabolism into the liver. This interpretation is supported by Saka at al. [13] and Fowler and DuVal [29] who claim that in case of aggression by xenobiotics, the hepatic metabolism of proteins is generally altered towards defense systems production and neoglucogenesis. Indeed, amino acids contained in protein compounds are catabolize under actions of transaminases, with ammonia production (highly toxic) leading to urea, the final form of nitrogenous waste excretion $[13,30]$. That excretion is done at the level of nephrons which is the structural-functional unit of kidney. Therefore, the increases in blood urea often reflect a nephropathy characterized by glomerular and tubular lesions [30]. This dysfunction is confirmed by the increase in blood creatinine which shows a decrease in excretory power of nephrons and even a tendency to renal failure $[13,29]$. Several authors have proven a close relationship between the intensity of lead poisoning and increased of blood urea, creatinine and uric acid.

The increase in blood uric acid apart from the gout that could result

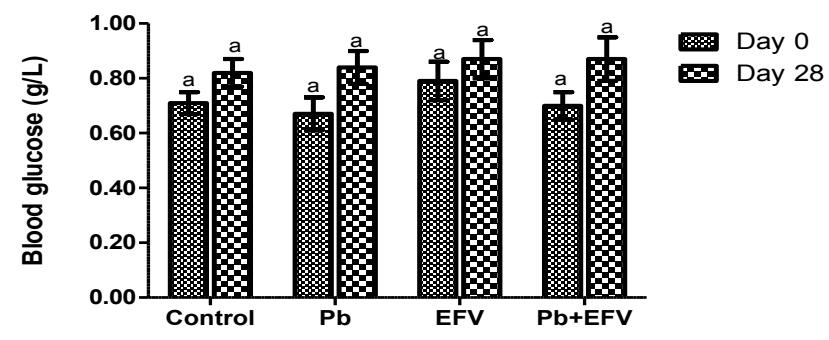

Values of Day 0 with same letter (a) are not significantly different

Figure 5: Blood glucose levels in control rats and in rats exposed to xenobiotics.

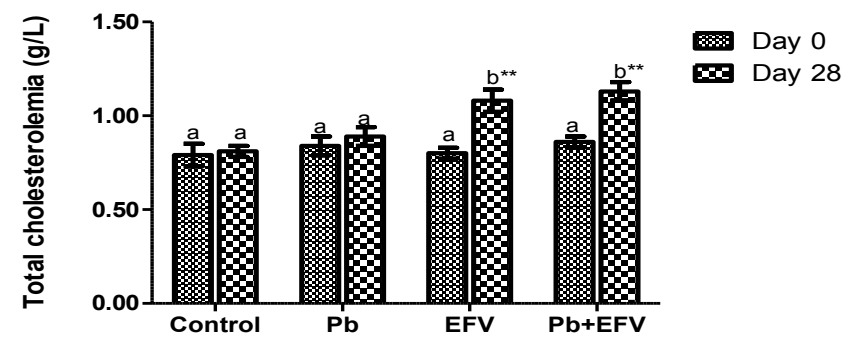

${ }^{* *} p<0.01$; Values of Day 0 with the same letter (a) are not significantly different. Values of Day 28 with letter (b) are statistically different from those of Day 0 in the same column

Figure 6: Total cholesterolemia levels in control rats and in rats exposed to xenobiotics. 


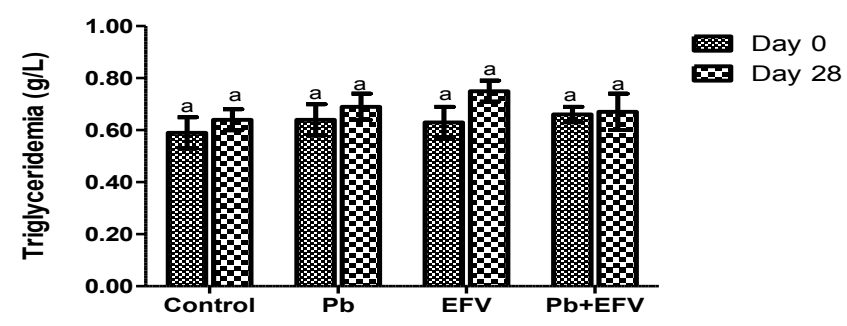

Values of Day 0 with same letter (a) are not significantly different Figure 7: Triglyceridemia levels in control rats and in rats exposed to xenobiotics.

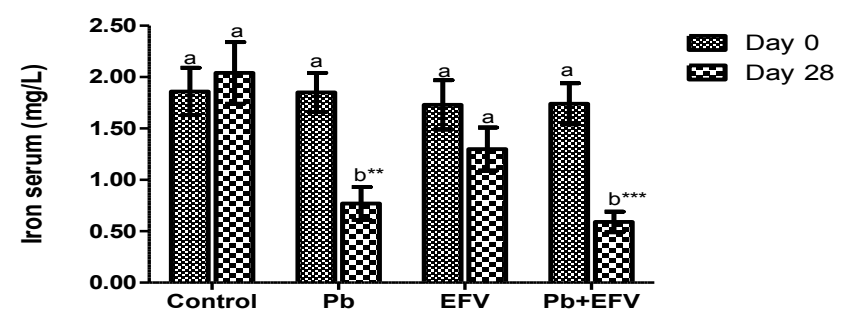

${ }^{*} p<0.01 ;{ }^{* * *} p<0.001$; Values of Day 0 with the same letter (a) are not significantly different. Values of Day 28 with letter (b) are statistically different from those of Day 0 in the same column

Figure 8: Iron serum levels in control rats and in rats exposed to xenobiotics.

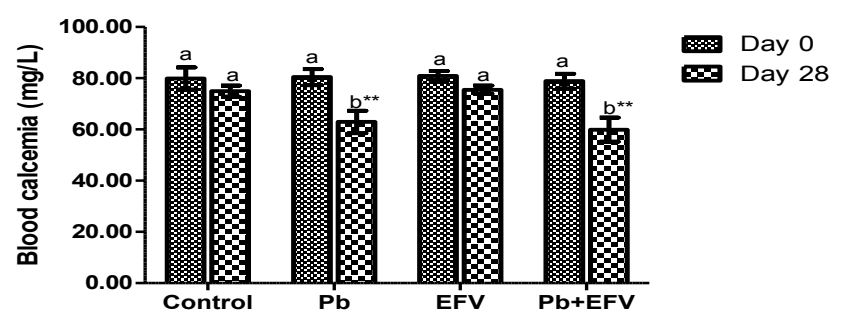

${ }^{* *} p<0.01$; Values of Day 0 with the same letter (a) are not significantly different. Values of Day 28 with letter (b) are statistically different from those of Day 0 in the same column

Figure 9: Blood calcemia levels in control rats and in rats exposed to xenobiotics.

is a corollary of saturnine nephropathy $[13,30]$. The hyperuricemia observed in our study is also a marker of oxidative stress linked to a proliferation of pro-oxidative substances such as reactive oxygen species as asserted in [31] and [32]. This assumption of oxidative stress related to lead exposure could justify the decrease in serum iron and blood calcium. Indeed, according to Probios [33], serum iron measured by the spectrophotometric method represents the pool of iron bound to carrier proteins such as transferrin, ferritin, ceruloplasmin and some chelating agents. Under normal physiological conditions, it is this type of iron that is detectable in the body [31]. But when, for any reason it is released, there is a decrease in the proportion measured. This free iron becomes pro-oxidant $[34,35]$ that catalyzes the reactive oxygen species formation. In addition, iron deficiency induced by lead absorption could also be explained by a competitive binding of lead and iron at the level of binding sites of iron [13]. This phenomenon of competition also exists between calcium and lead, hence lower calcemia observed in rats intoxicated by lead. That heavy metal takes the place of calcium on binding sites and disturbs several cellular or molecular processes mediated by the latter [33,36,37]. According to Hammad et al. [38] and Bruening et al. [39], the gastrointestinal absorption of lead can be significantly reduced by a diet rich in calcium and iron.

The insignificant change in blood glucose indicates that lead has not had adverse effects on the pancreas unlike findings of RamirezCervantes et al. cited by Saka et al [13]. These authors found a significant increase in blood glucose levels in subjects with saturnine and therefore directly attributed to the deleterious effects of lead acetate on the pancreas.

\section{Biochemical disturbances associated with Efavirenz}

The administration of Efavirenz at a daily dose of $20 \mathrm{mg} / \mathrm{kg}$ led to a significant decrease in total proteinemia and serum albumin as well as a moderate increase in blood uric acid and total cholesterolemia. Indeed, metabolism and mechanism of action of Efavirenz like those of many other antiretroviral drug promote oxidative stress [18,21]. Adjene et al have highlighted lipid peroxidation marked by the significant increase in Malondialdehyde level and decrease in blood superoxide dismutase in rats force-feeded with Efavirenz $(600 \mathrm{mg} / 70 \mathrm{~kg})$ for 30 days. The moderate hypercholesterolemia found after Efavirenz absorption in our study is strengthened by the report of Kirchner in 2012 [40] who assert that Efavirenz may be responsible of lypodystrophies characterized by increase in triglycerides and LDL cholesterol and with decreased HDL cholesterolemia.

\section{2-2. Impact of co-administration of lead acetate and Efavirenz}

In the conditions of our experiment, the alterations in biochemical parameters were more frequent and severe in rats exposed to lead than in those exposed to Efavirenz. Thus, the decreased rate of total protein and serum calcium as well as the increased rate of uremia and of uric acid were significantly higher under lead administration than Efavirenz. Indeed, the dose of $10 \mathrm{mg} / \mathrm{kg} /$ day of lead is high enough $[22,25]$. To induce a higher toxicity within a short period of time $(28$ days). Moreover, lower doses than the one used in our study were reported to induce evident toxicity in rats [41]. Taken separately, lead $[12,14,22,25,41]$ and Efavirenz $[18,19,21]$ induced toxicity effect. However, in this study, we did not detect additive effects or inhibition between the two compounds.

\section{Conclusion}

This study aimed to evaluate some biochemicals impacts associated with lead and Efavirenz intoxication. According to our results, it appears that the damages induced by lead were more important than those caused by Efavirenz. However, we did not find any significant additive or antagonist effect when both xenobiotics were co-administrated. Further studies are needed with the same dose of Efavirenz and a lower dose of lead which will be administered for a longer period of time.

\section{Acknowledgement}

The authors thank Mr Paul Kpossou and Mr Romain Dahoui for their technical assistance in blood biochemical parameters analysis performing.

\section{References}

1. Goldman LR (1995) Children-unique and vulnerable. Environmental risks facing children and recommendations for response. Environ Health Perspect 103 Suppl 6: 13-18.

2. Emmanuel E (2003) Evaluation des risques sanitaires et écotoxicologiques liés aux effluents hospitaliers. Thèse de Doctorat, Sciences et Techniques du Déchet, Ecole Doctorale de Chimie de Lyon.

3. Edorh AP, Agonkpahoun E, Gnandi K, Guédénon P, Koumolou L et al. 
Citation: Aïssi AK, Fah L, Akpovi CD, Klotoé JR, Dougnon VT, et al. (2014) Impact of Simultaneous Exposure to Lead and Efavirenz on Some Biochemical Markers in Wistar Rats. J Environ Anal Toxicol 4: 220. doi: 10.4172/2161-0525.1000220

Page 5 of 5

An assessment of the contamination of Achatina achatina by toxic metals in Okpara village. Int J Biol Chem Sci 3: 1428-1436.

4. Gnandi K, Tométy-Mensah F, Amey Apoh Y, Edorh P (2007) Distribution, biodisponibilité et bioaccumulation des métaux lourds dans le système lagunaire de Lomé, J Rech Sci Univ 9: 67-81.

5. Asuquo FE, Ita RE (2013) Assessment of flood-ebb tidal dynamics on heavy metal distribution in the nearshore waters of the gulf of Guinea. 7èmes Journées Scientifiques de l'Institut International de l'Ingénieurie de l'Eau et de l'Environnement (2iE), collection actes de conférences, Ouagadougou, Burkina Faso.

6. Adam S, Edorh PA, Totin H, Koumolou L, Amoussou E, et al. (2010) Pesticides et métaux lourds dans l'eau de boisson, les sols et les sédiments de la ceinture cotonnière de Gogounou, Kandi et Banikoara (Bénin). Int J Biol Chem Sci 3: 1141-1150.

7. Elégbédé B, Edorh AP, Aïssi KA, Koumolou L, Kaki C, et al. (2012) Blood lead levels and bio-markers of lead toxicity via the consumption of drinking water in Kérou (Benin) in watershed of the Niger. International Journal of Environmental Protection. 2:10-15

8. Fangnon B, Tohozin AY, Guedenon P, Edorh AP (2012) Conservation des produits agricoles et accumulation des métaux lourds dans les produits vivriers dans le département du Couffo (Benin). Journal of Applied Biosciences 57 4168-4176.

9. Guédénon P, Edorh AP, Kaki C, Yehouenou APE, Gnandi K, et al. (2012) Arsenic, Cadmium, Copper and Lead Accumulation in Water, Sediments and Fish Species of Oueme River in Bonou. British Journal of Pharmacology and Toxicology 4:13-20

10. Hounkpatin ASY, Edorh AP, Salifou S, Gnandi K, Koumolou L, et al. (2012) Assessment of exposure risk to lead and cadmium via fish consumption in the lacusrian village of Ganvié in Benin republic. Journal of Environmental Chemistry and Ecotoxicology 4:1-10.

11. Dougnon V, Edorh P, Bankolé H, Dougnon J, Klotoé JR, et al. (2013) Presence of lead in leaves of Solanum macrocarpon cultivated in Cotonou (Benin): role of poorly composted poultry manure. C R Biol 336: 261-264.

12. Fowler BA, Whittaker MH, Lipsky M, Wang G, Chen XQ (2004) Oxidative stress induced by lead, cadmium and arsenic mixtures: 30-day, 90-day, and 180-day drinking water studies in rats: an overview. Biometals 17: 567-568.

13. Saka S, Bahi A, Aouacheri W (2011) The effect of oxidative stress induced by lead acetate on the glutathione enzymatic system in rats. Annales de Toxicologie Analytique 23: 1-7.

14. Flora SJ, Mittal M, Mehta A (2008) Heavy metal induced oxidative stress \& its possible reversal by chelation therapy. Indian J Med Res 128: 501-523.

15. Cabell L, Ferguson C, Luginbill D, Kern M, Weingart A, et al. (2004) Differentia induction of heme oxygenase and other stress proteins in cultured hippocampal astrocytes and neurons by inorganic lead. Toxicol Appl Pharmacol 198: 49-60.

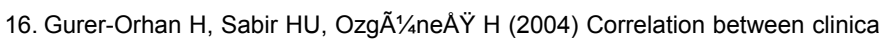
indicators of lead poisoning and oxidative stress parameters in controls and lead-exposed workers. Toxicology 195: 147-154.

17. Larroque B, Marret S (2000) Effets neurotoxiques du plomb chez l'enfant: aspects biologiques et épidémiologiques. Médecine thérapeutique / Pédiatrie 3: $474-381$.

18. Gutiérrez F, Navarro A, Padilla S, Antón R, Masiá M, et al. (2005) Prediction of neuropsychiatric adverse events associated with long-term efavirenz therapy, using plasma drug level monitoring. Clin Infect Dis 41: 1648-1653.

19. Adikwu E, Brambaifa N, Deo O, Oru-Bo PG (2013) Antiretroviral toxicity and oxidative stress. American Journal of Pharmacology and Toxicology 8: 187-196.

20. WHO (2013) Consolidated guidelines on the use of antiretroviral drugs for treating and preventing HIV infection. Recommandations for a public health approach.

21. Adjene JO, Avbunudiogba JA, Igbigbi PS (2012) Oxidative stress induced by chronic administration of Efavirenz on the intracranial visual relay centers of adult Wistar rats Biology and Medicine. Biology and Medicine 3:16-24.

22. Hassan AA, Jassim HM (2010) Effect of treating lactating rats with lead acetate and its interaction with vitamin $\mathrm{E}$ or $\mathrm{C}$ on neurobehavior, development and some biochemical parameters in their pups. Iraqi Journal of Veterinary Sciences 24: 45-52.
23. WHO (2010) Antiretroviral therapy for HIV infection in infants and children Towards universal access. Recommendations for a public health approach.

24. Descat $F(2002)$ Hématologie du rat : hémogramme et myélogramme. Thèse de doctorat, Ecole Nationale Vétérinaire de Toulouse.

25. Sundstrom $R$ (1985) Changes in the integrity of the blood-brain barrier in suckling rats with low dose lead encephalopathy. Acta Neuropathologica 68: 1-9.

26. P'an AY, Kennedy C (1989) Lead distribution in rats repeatedly treated with low doses of lead acetate. Environ Res 48: 238-247.

27. Missoun F, Slimani M, Aoues A (2010) Toxic effect of lead on kidney function in rat wistar. African Journal of Biochemistry Research 4: 021-027.

28. Moussa SA, Bashandy SA (2008) Biophysical and biochemical changes in the blood of rats exposed to lead toxicity. Romanian J Biophys 18:123-133.

29. Fowler BA, DuVal G (1991) Effects of lead on the kidney: roles of high-affinity lead-binding proteins. Environ Health Perspect 91: 77-80.

30. Ricoux C, Gasztowtt B (2005) Evaluation des risques sanitaires liés l'exposition de forts consommateurs produits de la pêche de rivière contaminés par des toxiques de l'environnement. Document de travail, France 65

31. Pincemail J, Meurisse M, Limet R, Defraigne JO (1999) L'évaluation du stress oxydatif d'un individu: une réalité pour le médecin, Vaisseaux, Cœur, Poumon $4: 148-54$

32. Valko M, Leibfritz D, Moncol J, Cronin MT, Mazur M, Telser J (2007) Free radicals and antioxidants in normal physiological functions and human disease. Int J Biochem Cell Biol 39: 44-84.

33. Probios SA (2012) Le stress oxydant. Consulté le 29 mars.

34. Britton RS, Leicester KL, Bacon BR (2002) Iron toxicity and chelation therapy. Int J Hematol 76: 219-228.

35. Burkitt MJ, Milne L, Raafat A (2001) A simple, highly sensitive and improved method for the measurement of bleomycin-detectable iron: the 'catalytic iron index' and its value in the assessment of iron status in haemochromatosis. Clin Sci (Lond) 100: 239-247.

36. Simons TJ (1986) Cellular interactions between lead and calcium. Br Med Bull 42: $431-434$

37. Pounds JG, Long GJ, Rosen JF (1991) Cellular and molecular toxicity of lead bone. Environ Health Perspect 91: 17-32.

38. Hammad TA, Sexton M, Langenberg P (1996) Relationship between blood lead and dietary iron intake in preschool children. A cross-sectional study. Ann Epidemiol 6: 30-33.

39. Bruening K, Kemp FW, Simone N, Holding Y, Louria DB, et al. (1999) Dietary calcium intakes of urban children at risk of lead poisoning. Environ Health Perspect 107: 431-435.

40. Kirchner TJ (2012) A Tolerability Review of Non-Nucleoside Reverse Transcriptase Inhibitors: Focus on Laboratory Measures of Clinical Relevance. J Antivir Antiretrovir 4: 094-100.

41. Okediran OS, Solomon AE, Clara TF, Esther AO, Rahaman S (2010) Investigation of subchronic lead intoxication on blood indices of male rats. Global Vet 4: 532-535. 